\title{
Redox Mediated Control of Electrochemical Potential in Liquid Cell Electron Microscopy
}

Authors: Ivan A. Moreno-Hernandez ${ }^{1}$, Michelle F. Crook $^{1}$, Justin C. Ondry ${ }^{1,3}$, and A. Paul Alivisatos $^{1-4 *}$

\section{Affiliations:}

${ }^{1}$ Department of Chemistry, University of California, Berkeley, California 94720, United States

${ }^{2}$ Materials Sciences Division, Lawrence Berkeley National Laboratory, Berkeley, California 94720, United States

${ }^{3}$ Kavli Energy NanoScience Institute, Berkeley, California 94720, United States

${ }^{4}$ Department of Materials Science and Engineering, University of California, Berkeley, California 94720, United States

*Corresponding author. Email: paul.alivisatos@berkeley.edu

\section{Supporting methods}

\section{Chemicals}

All chemicals were used as received, including hydrochloric acid ( $\mathrm{HCl}$, Sigma-Aldrich), hexadecyltrimethylammonium chloride (CTAC, $>95.0 \%, \mathrm{TCI})$, potassium bromide $(\mathrm{KBr}, 99.99 \%$, Acros Organics), palladium(II) chloride $\left(\mathrm{PdCl}_{2}, 99.999 \%\right.$, Acros Organics), citric acid monohydrate (99.5\%, Acros Organics), gold(III) chloride trihydrate $\left(\mathrm{HAuCl}_{4}, 99.99 \%\right.$, Alfa Aesar), sodium borohydride $\left(\mathrm{NaBH}_{4}, 98 \%\right.$, Alfa Aesar), L-ascorbic acid (ACS grade, Fisher Chemical), potassium tetrachloroplatinate(II) $\left(\mathrm{K}_{2} \mathrm{PtCl}_{4}, 99.9 \%\right.$, Alfa Aesar), sodium pyrophosphate dibasic $\left(\mathrm{Na}_{2} \mathrm{H}_{2} \mathrm{P}_{2} \mathrm{O}_{7},>99.0 \%\right.$, Sigma-Aldrich), chromium(III) chloride hexahydrate $\left(\mathrm{CrCl}_{3}, 98 \%\right.$, Acros Organics), cerium(III) chloride heptahydrate $\left(\mathrm{CeCl}_{3}, 99.9 \%\right.$, Sigma-Aldrich), europium(III) acetate hydrate (99.9\%, Sigma-Aldrich), vanadium(IV) oxide $\left(\mathrm{V}_{2} \mathrm{O}_{4}, 99 \%\right.$, Alfa Aesar), magnesium chloride hexahydrate (MgCl2, ACS grade, Sigma-Aldrich), and sodium persulfate $(>99 \%$, Sigma-Aldrich). Deionized water was obtained from a Millipore deionizer water system.

Nanoparticle synthesis

Palladium nanocubes were synthesized according to a previously reported procedure with slight modifications. ${ }^{1} \mathrm{~A} 10 \mathrm{~mL}$ solution of $12.5 \mathrm{mM} \mathrm{CTAC}$ and $2 \mathrm{mM} \mathrm{KBr}$ was prepared, and 0.5 $\mathrm{mL}$ of $10 \mathrm{mM} \mathrm{H}_{2} \mathrm{PdCl}_{4}$ prepared with $\mathrm{PdCl}_{2}$ and $200 \mathrm{mM} \mathrm{HCl}$ was added. The solution was heated to $95{ }^{\circ} \mathrm{C}$ for $5 \mathrm{~min}$ and stirred. Subsequently, $80 \mu \mathrm{L}$ of freshly prepared L-ascorbic acid was added. The reaction was allowed to proceed for $30 \mathrm{~min}$ then cooled to room temperature. The resulting 
palladium nanocubes were washed two times with water and centrifuged and were concentrated to a $1 \mathrm{~mL}$ colloidal suspension with deionized water.

Gold-coated palladium nanocubes were prepared with modifications to a previously reported procedure. ${ }^{2}$ Palladium nanocubes were prepared with the procedure described above. A $4 \mathrm{~mL}$ solution of $1 \mathrm{mM} \mathrm{CTAC}$ and $0.2 \mathrm{mM} \mathrm{KBr}$ was prepared, and $50 \mu \mathrm{L}$ of the concentrated $\mathrm{Pd}$ nanocrystal suspension and $50 \mu \mathrm{L}$ of $100 \mathrm{mM}$ citric acid were added. The solution was stirred and heated to $95{ }^{\circ} \mathrm{C}$ for $5 \mathrm{~min}$. Subsequently, $25-100 \mu \mathrm{L}$ of $1 \mathrm{mM} \mathrm{HAuCl}_{4}$ was added and the solution was allowed to react for $15 \mathrm{~min}$. The nanocrystals were washed with water several times and concentrated to a $1 \mathrm{~mL}$ colloidal suspension with deionized water. We note that the formation of shells was observed with citric acid in this study, whereas the initial study observed shell formation with ascorbic acid. The difference could be attributed to the different Pd nanocrystal size and type of ligand used in this study.

Truncated gold nanocubes were synthesized according to a previously reported method with a few modifications. ${ }^{3} \mathrm{~A} 10 \mathrm{~mL}$ solution of $0.25 \mathrm{mM} \mathrm{HAuCl}_{4}$ and $100 \mathrm{mM} \mathrm{CTAC}$ was prepared, and $0.45 \mathrm{~mL}$ of an ice-cold $20 \mathrm{mM} \mathrm{NaBH}_{4}$ solution was added to synthesize gold seeds. The solution was allowed to age for 1 hour at room temperature. Two solution vials, labeled $\mathrm{A}$ and $\mathrm{B}$, were prepared by adding $160 \mathrm{mg}$ of CTAC, $4.813 \mathrm{~mL}$ of water, $125 \mu \mathrm{L}$ of $10 \mathrm{mM} \mathrm{HAuCl}_{4}, 5 \mu \mathrm{L}$ of 10 $\mathrm{mM} \mathrm{NaBr}$, and $45 \mu \mathrm{L}$ of $40 \mathrm{mM}$ ascorbic acid. Large seeds were grown by adding $1 \mathrm{~mL}$ of the seed solution to vial A and the solution was mixed for 5 seconds. Subsequently, $12.5 \mu \mathrm{L}$ of the solution in vial A was added to vial B and mixed for 10 seconds. The solution in vial B was allowed to react for 15 minutes. The resulting nanocrystals were washed with water several times, and were centrifuged to a $1 \mathrm{~mL}$ colloidal suspension.

Platinum nanocubes were synthesized according to a previously reported procedure. ${ }^{4} \mathrm{~A} \mathrm{Pt}$ pyrophosphato complex solution was obtained by preparing a $2 \mathrm{~mL}$ solution containing $5 \mathrm{mM}$ $\mathrm{K}_{2} \mathrm{PtCl}_{4}, 5 \mathrm{mM} \mathrm{Na} \mathrm{H}_{2} \mathrm{P}_{2} \mathrm{O}_{7}$, and $2.5 \mathrm{mM} \mathrm{KBr}$. A $2 \mathrm{~mL}$ solution of $2 \mathrm{mg}$ per $\mathrm{mL} \mathrm{NaBH}_{4}$ was prepared with ice-cold water. A reaction vial was prepared with $3 \mathrm{~mL}$ of water, and heated to 95 ${ }^{\circ} \mathrm{C}$ for $5 \mathrm{~min}$ and stirred. The Pt complex solution and $\mathrm{NaBH}_{4}$ solution were injected into the reaction vial at a rate of $4 \mathrm{~mL}$ per hour with a syringe pump. The resulting nanocrystals were wasted with water and centrifuged to a $1 \mathrm{~mL}$ colloidal suspension.

\section{Electrochemical characterization}

A 2.0 M hydrochloric acid stock solution was used to prepare a $100 \mathrm{mM}$ hydrochloric acid electrolyte. A digital potentiostat (SP-200, Bio-Logic Science Instruments) was used to acquire electrochemical data. A mercury-mercury sulfate electrode with a standard potential of $0.68 \mathrm{~V}$ vs. SHE was used as a reference electrode. A three-neck round bottom flask was used as the electrochemical cell, and cleaned with aqua regia prior to use. Approximately $20 \mathrm{~mL}$ of $100 \mathrm{mM}$ $\mathrm{HCl}$ was used as the electrolyte for all experiments. The working, reference, and counter electrodes consisted of a metal electrode, a mercury/mercury sulfate electrode, and a carbon rod, respectively. The Pd metal electrode was constructed from a Pd cylinder (99.95\%, Kurt J. Lesker Company) bonded to a copper wire and encapsulated with epoxy. Electrodes made of Au and Pt were acquired commercially ( $\mathrm{CH}$ Instruments, Inc.). The electrodes were polished mechanically prior to each use. The $\mathrm{Pd}, \mathrm{Au}$, and $\mathrm{Pt}$ electrodes had geometric areas of $0.317,0.031$, and $0.031 \mathrm{~cm}^{-2}$, 
respectively. Cyclic voltammetry data were collected at a scan rate of $10 \mathrm{mV} \mathrm{s}^{-1}$. The solution resistance was determined for each experiment with impedance measurements. The series resistance was in the range of $23-71 \Omega$ and the electrochemical data were corrected with Ohm's law to remove resistance losses, with a typical correction being less than $10 \mathrm{mV}$ at $1 \mathrm{~mA} \mathrm{~cm}^{-2}$. Cyclic voltammetry data was used to determine the maximum etch rate of the metal nanocrystals for a certain potential, assuming 100\% Faradaic efficiency towards metal dissolution. The expected dissolution products of $\mathrm{Pd}, \mathrm{Au}$, and $\mathrm{Pt}$ were $\mathrm{PdCl}_{4}{ }^{2-}, \mathrm{AuCl}_{4}{ }^{-}$, and $\mathrm{PtCl}_{4}{ }^{2-}$, respectively (Table S1). The assumption of $100 \%$ Faradaic efficiency is expected to apply at potentials below the chlorine evolution reaction, as observed for $\mathrm{Pd}$ and $\mathrm{Au}$ electrodes dissolving. While the current observed for Pt could be attributed to the chlorine evolution reaction and platinum dissolution, the absence of dissolution at potentials below $1.36 \mathrm{~V}$ vs. SHE indicates that Pt is more kinetically stable than $\mathrm{Pd}$ or $\mathrm{Au}$. The current density can be converted to an etch rate with equation 1:

$$
R=\frac{J}{n F \rho}
$$

Where $J$ is the current per area, $n$ is the number of electrons transferred per dissolved metal atom, $F$ is Faraday's constant, and $\rho$ is the molar density of the metal.

\section{Energy-dispersive $x$-ray spectroscopy mapping}

High angle annular dark field (HAADF) STEM and STEM EDS maps were collected for goldcoated palladium nanocubes on the FEI TitanX 60-300 microscope at the National Center for Electron Microscopy, Molecular Foundry, Lawrence Berkeley National Laboratory (LBNL). An FEI low background double tilt holder was used for all experiments. HAADF STEM was performed at $200 \mathrm{kV}$ with a beam convergence semi-angle of $10 \mathrm{mrad}$ using a Fischione high-angle annular dark-field (HAADF) detector with an inner semiangle of 63 mrad. STEM-EDS mapping was performed at $200 \mathrm{kV}$ with a typical probe current of $500 \mathrm{pA}$ using an FEI Super-X Quad windowless detector with a solid angle of 0.7 steradians. Data was collected using the Bruker Esprit software utilizing drift correction. Quantification was performed using the Bruker Esprit software using the Cliff-Lormer method. Line-profiles were extracted using the Bruker Esprit software. Maps and quantification were performed using the $\mathrm{K}$ series for $\mathrm{Pd}$ and the $\mathrm{L}$ series for $\mathrm{Au}$.

Image analysis

TEM images were analyzed with scripts written in MATLAB. The videos were converted from the Gatan DigitalMicrograph Image Document 4 file format to the TIFF image format. The images for each experiment were stored in separate folders and the images were labeled with increasing integer values. The initial experiment frame, defined as the frame at which the beam dose was increased to its final value, was determined for each experiment by observing the image noise and intensity. An analysis script determined the initial frame and final frames for each experiment. The frames were sub-divided into 5 sections, and the operator would be asked to mark the position of the nanocrystal for each of the 5 sections with a graphical user interface. The script linearly interpolated the position of the nanocrystal for all frames from the 5 inputs, cropped a region of interest around the nanocrystal, and performed image segmentation algorithms to determine the outline of the nanocrystal. The reported nanocrystal size was defined as the square root of the 
projected area, $\mathrm{A}^{(1 / 2)}$, which is the exact formula for a perfectly oriented cube. The scripts used in this study are provided in the Alivisatos Github repository. ${ }^{5}$

\section{Homogeneous radiolysis chemical reaction network model}

A kinetic model was developed to understand the effect of cerium additives on the chemical environment during liquid cell electron microscopy experiments. The model utilizes the MATLAB code written by Schneider et al., which is an implementation of the kinetic model by Elliot and McCracken. ${ }^{6-7}$ The model used in this study includes 73 previously reported reactions involving species derived from water. ${ }^{6}$ Additionally, the model includes 20 reactions involving chloride and 3 reactions involving cerium (Table S5). The kinetic model was solved for the homogeneous case by numerically solving a set of coupled differential equations (Eq. 2).

$$
\frac{\partial C_{i}}{\partial t}=\sum_{j, k \neq i} k_{j k} C_{j} C_{k}-\sum_{j} k_{i j} C_{i} C_{j}+R_{i}
$$

Where $k_{j k}$ and $k_{i j}$ are reaction rate constants, $C_{i}, C_{j}$, and $C_{k}$ are reactant concentrations, and $R_{i}$ is the electron beam induced generation of species. The generation of radiolysis species was modeled according to previously reported generation values at a dose rate of $1200 \mathrm{e}^{-} \AA^{-2} \mathrm{~s}^{-1}$ unless otherwise stated. ${ }^{6}$ The MATLAB implementation of this model is provided in the Alivisatos Github repository. For simulations that are shown on Fig. S5 and Fig. S6, the kinetic model was solved for 20,402 different initial conditions. The conditions correspond combinations of 101 electron beam dose conditions logarithmically spaced from 1 to $1,000 \mathrm{e}^{-} \AA^{-2} \mathrm{~s}^{-1}, 101$ initial Ce(III) concentration conditions linearly spaced from 0 to $100 \mathrm{mM}$, and two chloride conditions of $0 \mathrm{mM}$ and $100 \mathrm{mM} \mathrm{Cl}^{-}$. For each condition, the simulation was solved for 1,000 seconds and the final concentration of each species was considered to be the steady-state concentration. The steady-state concentrations of atomic hydrogen, hydroxyl radicals, $\mathrm{Ce}(\mathrm{IV})$, and $\mathrm{Cl}_{3}{ }^{-}$are plotted on Fig. S5 and Fig. S6 on the z-axis as a color plot, with the $\mathrm{x}$ - and $\mathrm{y}$-axis of the plot corresponding to the initial $\mathrm{Ce}(\mathrm{III})$ concentration and the electron beam dose, respectively.

\section{Nanocrystal etching trajectory model}

A model was derived to understand the etching trajectories of nanocrystals under electrochemical control. The etching of nanocrystals is due to nanocrystal oxidation by an oxidized species. The volumetric etching rate was assumed to be linear with oxidant concentration [O], and nanocrystal surface area with a surface reaction rate constant of $r$ which has units of nm s${ }^{-1} \mathrm{M}^{-1}$ (Eq. 3).

$$
\frac{\partial V}{\partial t}=-r[O] A
$$

The oxidant is formed by the reaction between a reduced species and hydroxyl radicals. Additionally, the oxidant can react with reducing species such as solvated electrons or atomic hydrogen to regenerate the reduced species. These dynamics can be modeled with a chemical network model as described above, which indicate that the oxidant will reach a steady-state concentration over time. A simplified model of these dynamics can be derived by assuming first- 
order oxidation kinetics of the reduced species to a steady-state concentration $\left[O_{S S}\right]$, assuming that the initial oxidant concentration is zero (Eq. 4-5).

$$
\begin{gathered}
\frac{\partial[O(t)]}{\partial t}=k\left(\left[O_{s S}\right]-[O(t)]\right) \\
{[O(t)]=\left[O_{s s}\right]\left(1-e^{-k t}\right)}
\end{gathered}
$$

The volume of the nanocrystal over time can be obtained by solving the following differential equation, assuming that the nanocrystal shape is cubic during the etching process and that the oxidant concentration follows the derived expression. The initial volume of the nanocrystal is $V_{i}$ (Eq. 6-8).

$$
\begin{gathered}
\frac{\partial V(t)}{\partial t}=-r[O(t)] A(t)=-r[O(t)] 6 V(t)^{\frac{2}{3}} \\
\frac{\partial V(t)}{\partial t}=-r\left[O_{s S}\right]\left(1-e^{-k t}\right) 6 V(t)^{\frac{2}{3}} \\
V(t)=\left(V_{i}^{\frac{1}{3}}-2 r\left[O_{s S}\right]\left[\frac{e^{-k t}-1}{k}+t\right]\right)^{3}
\end{gathered}
$$

The steady-state concentration of the oxidant cannot be determined experimentally during graphene liquid cell electron microscopy experiments with current techniques. However, the product of the surface reaction rate constant and the steady-state oxidant concentration, $r\left[O_{s s}\right.$, can be fit to experimentally determined etching trajectories. This model allows etching trajectories to be fit with only two parameters other than the initial nanocrystal volume: the homogeneous reaction kinetics of oxidant generation, $k$, and the heterogeneous surface reaction kinetics of nanocrystal etching, $r\left[O_{s s}\right]$. The constant $r\left[O_{s s}\right]$ has units of $\mathrm{nm} \mathrm{s}^{-1}$, and will be referred to as the surface etching rate $R$ (Eq. 9). This equation can be expressed in terms of nanocrystal length $\mathrm{L}$, or size, instead of volume (Eq. 10).

$$
\begin{gathered}
V(t)=\left(V_{i}^{\frac{1}{3}}-2 R\left[\frac{e^{-k t}-1}{k}+t\right]\right)^{3} \\
L(t)=L_{i}-2 R\left[\frac{e^{-k t}-1}{k}+t\right]
\end{gathered}
$$

At long time scales relative to $\mathrm{k}^{-1}$ the oxidant concentration will be a constant, resulting in a constant etching rate in terms of nanocrystal length (Eq. 11).

$$
\frac{\partial L(t)}{\partial t}=-2 R t
$$




\section{Supporting discussion}

Experiments in liquid cells containing $100 \mathrm{mM} \mathrm{HCl}$ and $10 \mathrm{mM} \mathrm{MgCl}_{2}$ indicate no substantial etching within 30 seconds of irradiation for $\mathrm{Au}$ and Pt nanocrystals, and inconsistent etching behavior for $\mathrm{Pd}$ nanocrystals (Fig. S3). The etching of Pd nanocrystals was observed in approximately 1 out of every 3 etching trajectories at $1200 \mathrm{e}^{-} \AA^{-2} \mathrm{~s}^{-1}$. Solutions containing chloride are expected to form $\mathrm{Cl}_{2}{ }^{-}$and $\mathrm{Cl}_{3}{ }^{-}$due to electron-water interactions ${ }^{8}$. These halide species have standard potentials that range from $1.42 \mathrm{~V}$ to $2.13 \mathrm{~V}$ vs. SHE, indicating that they could spontaneously dissolve the nanocrystals studied herein (Table S1). However, the reduction of $\mathrm{Cl}_{2}{ }^{-}$ and $\mathrm{Cl}_{3}{ }^{-}$requires substantial structural changes, which could decrease the kinetic reactivity of these species on nanocrystal surfaces. As Pd has a lower potential for etching compared to $\mathrm{Au}$ and $\mathrm{Pt}$, it is expected that the high driving force for etching $\mathrm{Pd}$ with $\mathrm{Cl}_{2}{ }^{-}$or $\mathrm{Cl}_{3}{ }^{-}$was sufficient to overcome kinetic barriers for reducing these oxidants.

Water radiolysis results in the formation of $\mathrm{H}_{2}, \mathrm{O}_{2}$, and $\mathrm{H}_{2} \mathrm{O}_{2}$ at steady-state concentrations that increase with increasing electron dose (Fig. S5). The addition of $\mathrm{Ce}$ (III) results in an increase of $\mathrm{H}_{2}$ produced, whereas $\mathrm{O}_{2}$ production decreases (Fig. S5). The steady-state concentration of $\mathrm{H}_{2} \mathrm{O}_{2}$ decreases with $\mathrm{Ce}(\mathrm{III})$ added, then increases at higher $\mathrm{Ce}(\mathrm{III})$ concentrations. The concentration of $\mathrm{H}_{2} \mathrm{O}_{2}$ is $16.9 \mathrm{mM}$ at an electron dose of $1,000 \mathrm{e}^{-} \AA^{-2} \mathrm{~s}^{-1}$ without $\mathrm{Ce}$ (III) and a minimum of $11 \mathrm{mM}$ is obtained when $50 \mathrm{mM} \mathrm{Ce}$ (III) is added (Fig. S5). The pH is insensitive to the electron beam dose without Ce(III) added, but increases with dose and Ce(III) concentration when $\mathrm{Ce}(\mathrm{III})$ is present. The $\mathrm{pH}$ increases from 1.00 to 1.03 with $10 \mathrm{mM} \mathrm{Ce}(\mathrm{III})$ added at an electron dose of $1,000 \mathrm{e}^{-} \AA^{-2} \mathrm{~s}^{-1}$ (Fig. S6). A low redox additive concentration could lead to improved precision for reactions that are sensitive to $\mathrm{pH}$ changes. Simulations of solutions containing $100 \mathrm{mM} \mathrm{Cl}^{-}$exhibit trends that are different than observed without $\mathrm{Cl}^{-}$(Fig. S6). The steady-state concentrations of $\mathrm{H}_{2}, \mathrm{O}_{2}$, and $\mathrm{H}_{2} \mathrm{O}_{2}$ increase when $\mathrm{Cl}^{-}$is present and are less sensitive to electron dose and $\mathrm{Ce}$ (III) concentration (Fig. S6). The effect of Ce(III) and electron dose on $\mathrm{pH}$ also decreases with $\mathrm{Cl}^{-}$added (Fig. S6). In solutions containing $100 \mathrm{mM} \mathrm{Cl}^{-}$at an electron dose of $1,000 \mathrm{e}^{-} \AA^{-2} \mathrm{~s}^{-1}$, the $\mathrm{pH}$ is 1.036 without $\mathrm{Ce}$ (III) and 1.041 with $10 \mathrm{mM} \mathrm{Ce}$ (III) (Fig. S6). The results from simulations indicate that the addition of $\mathrm{Ce}$ (III) to water substantially decreases the steadystate concentration of atomic hydrogen and hydroxyl radicals, and results in the partial oxidation of $\mathrm{Ce}(\mathrm{III})$ to $\mathrm{Ce}(\mathrm{IV})$ (Fig. S4, S5). The steady-state concentration of $\mathrm{Ce}(\mathrm{IV})$ exhibits regions of electron beam dose insensitivity and is several orders of magnitude higher than the steady-state concentration of radical species (Fig. S5, S6). The simulations also indicate that the addition of $\mathrm{Cl}^{-}$ and $\mathrm{Ce}(\mathrm{III})$ can decrease the effect of radical species on electrochemical reactions. However, the formation of $\mathrm{H}_{2}, \mathrm{O}_{2}$, or $\mathrm{H}_{2} \mathrm{O}_{2}$ could lead to complex behavior if electrochemical reactions of interest are affected by these species. Since more $\mathrm{H}_{2}$ is generated compared to $\mathrm{O}_{2}$, it is expected that bubbles observed during experiments are mostly composed of $\mathrm{H}_{2}$ gas. The bubbles could act as a reducing agent, leading to reactions being observed at the bubble/liquid interface. $\mathrm{H}_{2} \mathrm{O}_{2}$ forms at steady-state concentrations in the $\mathrm{mM}$ range in acid for typical imaging conditions, and could act as a strong oxidant in these cases.

The effect of $\mathrm{V}(\mathrm{IV}), \mathrm{Cr}(\mathrm{III})$, and $\mathrm{Ce}(\mathrm{III})$ redox additives on the electrochemical environment in graphene liquid cells was probed by analyzing the etching trajectories of $\mathrm{Pd}, \mathrm{Au}$, and $\mathrm{Pt}$ nanocrystals in the presence of each of the redox couples (Fig. 2). The observed etch rate distributions tend to exhibit a positive skew, as indicated by a few etch experiments exhibiting a 
fast etch rate compared to the median (Fig. 2). Thus, the etch rates are reported as the median and the first and third quartiles instead of the mean, which would be more appropriate for normal distributions. Using the electrochemical framework described earlier, it is expected that only Pd would dissolve in a liquid cell prepared with V(IV), while Au and Pt remain stable. The calculated median etch rates of $\mathrm{Pd}, \mathrm{Au}$, and $\mathrm{Pt}$ nanocrystals in $\mathrm{V}(\mathrm{IV})$ containing liquid cells are $0.08,0.01$, and $0.00 \mathrm{~nm} \mathrm{~s}^{-1}$, respectively (Fig. 2A). The stability of Au and Pt nanocrystals in V(IV) containing liquid cells is consistent with the $1.00 \mathrm{~V}$ vs. SHE standard potential of the $\mathrm{V}(\mathrm{IV}) / \mathrm{V}(\mathrm{V})$ redox couple and the kinetic potentials for metal dissolution measured with cyclic voltammetry (Fig. S2, Table S3). For the liquid cells prepared with $\mathrm{Cr}$ (III), previous studies indicate that electron-water interactions result in the partial oxidation of $\mathrm{Cr}(\mathrm{III})$ to $\mathrm{Cr}(\mathrm{VI})$ via several intermediates, while solutions that initially contain $\mathrm{Cr}(\mathrm{VI})$ are partially reduced to $\mathrm{Cr}$ (III) (Table S2). It is expected that these dynamics will lead to the formation of the $\mathrm{Cr}(\mathrm{III}) / \mathrm{Cr}(\mathrm{VI})$ redox couple in graphene liquid cells. The $\mathrm{Cr}(\mathrm{III}) / \mathrm{Cr}$ (VI) redox couple has a standard potential of $1.38 \mathrm{~V}$ vs. SHE which is only sufficiently positive to dissolve $\mathrm{Pd}$ and $\mathrm{Au}$ nanocrystals, while Pt nanocrystals would remain stable. Accordingly, the calculated median etch rates of $\mathrm{Pd}, \mathrm{Au}$, and $\mathrm{Pt}$ nanocrystals were 0.50 , 0.31 , and $0.00 \mathrm{~nm} \mathrm{~s}^{-1}$, respectively (Fig. 2B). Lastly, the $\mathrm{Ce}(\mathrm{III}) / \mathrm{Ce}(\mathrm{IV})$ redox couple has a standard potential of $1.466 \mathrm{~V}$ vs. SHE, which is sufficient to etch all nanocrystals studied herein. $\mathrm{Pd}, \mathrm{Au}$, and Pt nanocrystals all dissolved in liquid cells containing $\mathrm{Ce}(\mathrm{III})$, with median rates of 0.59 (0.33 $-0.84), 1.39(1.08-1.75)$, and $0.19(0.17-0.83) \mathrm{nm} \mathrm{s}^{-1}$, respectively (Fig. 2C). For etching experiments with $\mathrm{V}(\mathrm{IV})$ and $\mathrm{Cr}(\mathrm{III})$, the etch rates observed are consistent with the trend expected from kinetic considerations (Table S4). However, for etching experiments with Ce(IV) the etching behavior is not directly consistent with this trend, since the etch rate of $\mathrm{Pd}$ is lower than $\mathrm{Au}$. Analysis of the etching behavior of $\mathrm{Pd}, \mathrm{Au}$, and $\mathrm{Pt}$ indicates that all etch rates increase with increasing potential of the redox couple (Table S4). Thus, the discrepancy can be attributed to the etch rate of $\mathrm{Pd}$ not increasing to a rate required to maintain the $\mathrm{Pd}>\mathrm{Au}>\mathrm{Pt}$ etch rate trend. In bulk electrochemical experiments $\mathrm{Au}$ and $\mathrm{Pt}$ are observed to dissolve at exponentially increasing rates with increasing potential, whereas Pd exhibits more complex behavior. ${ }^{9-10}$ In these studies, $\mathrm{Pd}$ exhibits an etching onset potential that is lower than $\mathrm{Au}$ or $\mathrm{Pt}$, consistent with kinetic considerations. However, the etch rate of $\mathrm{Pd}$ is insensitive to the applied potential from $1.2-1.45$ V vs. RHE and decreases at potentials above this range. This behavior is attributed to the formation of a passivating $\mathrm{Pd}$ oxide layer that kinetically inhibits dissolution. ${ }^{9-10} \mathrm{Pd}$ can spontaneously form $\mathrm{PdO}$ at potentials above $0.79 \mathrm{~V}$ vs. SHE (Table S1). Thus, we conclude that the small increase in etch rate observed for $\mathrm{Pd}$ in graphene liquid cells containing $\mathrm{Ce}$ (IV) compared to $\mathrm{Cr}$ (III), which leads to a discrepancy with the $\mathrm{Pd}>\mathrm{Au}>\mathrm{Pt}$ etch rate trend, is consistent with the etching behavior of bulk Pd electrodes.

The effects of various parameters such as electron dose, liquid thickness, and aberration correction on the resolution of liquid cell experiments have been extensively discussed in previous work. ${ }^{11}$ Liquid cell electron microscopy is typically used to observe heterogeneous mixtures such as nanocrystals or biological structures dispersed in a liquid, since imaging the structure of a completely homogeneous liquid is not typically possible with a modern electron microscope. At high electron doses, liquid cells with a thickness below $300 \mathrm{~nm}$ can achieve sub-nm resolution for the solid phase. ${ }^{11}$ Our group has previously reported the ability to form graphene liquid cells with liquid thicknesses in the range of 6 to $200 \mathrm{~nm}$, which allows imaging at atomic resolution. ${ }^{12}$ Redox additives to not inherently increase the resolution of imaging studies. However, the ability to control electrochemical reactions with redox couples during liquid cell electron microscopy studies 
enables electrochemical reactions to be studied at higher electron doses and with thinner liquid thicknesses, which facilitates imaging at near-atomic resolution.

To further generalize our hypothesis of redox additive potential control, we identified conditions that enable Pd nanocrystals to be imaged at near-atomic resolution without substantial dissolution. Europium readily dissolves in acid, forms the $\mathrm{Eu}(\mathrm{II}) / \mathrm{E}$ (III) redox couple with a standard potential of $-0.35 \mathrm{~V}$ vs. SHE (Table S1), and interacts through redox reactions with radical species generated during water radiolysis (Table S2). These properties could enable Eu additives to further decrease the effective electrochemical potential compared to V(IV), and enable highresolution studies of sensitive materials such as Pd. Figure S9 shows high resolution images of Pd nanocrystals under dry TEM conditions and within a graphene liquid cell prepared with $10 \mathrm{mM}$ $\mathrm{Eu}(\mathrm{III})$ acetate and $100 \mathrm{mM} \mathrm{HCl}$. In both cases lattice fringes can be readily observed, indicating that the ability to obtain near-atomic resolution is not affected by the presence of a redox additive. The Pd nanocrystals were stable in graphene liquid cells prepared with Eu(III) acetate (Fig. S9), indicating that this additive was effective at reducing the etching observed in liquid cell studies without a redox additive (Fig. S3).

An alternative to the hypothesis of redox additive potential control is that redox couples only act as radical scavengers, and the observed reactivity is due to electron-beam induced chemical reactions from direct radiolysis products. The simulations presented in Figure S6, which were developed from experimentally observed reaction rates (Table S5), indicate that the addition of $\mathrm{Ce}(\mathrm{III})$ to solutions containing chloride does not substantially affect the concentrations of radiolysis products due to scavenging by chloride. Thus, we would expect no substantial change in the etching behavior of Au nanocrystals in acidic chloride solutions when $\mathrm{Ce}$ (III) is present if radiolysis products were the only species interacting with the nanocrystal. However, we observe that Au nanocrystals etch at a rate of $1.08-1.75 \mathrm{~nm} \mathrm{~s}^{-1}$ with Ce present (Fig. 2C) and without Ce etching does not occur (Fig. S3), indicating that the etching behavior is not consistent with the hypothesis that only radiolysis products interact with the nanocrystal. The experiments demonstrated in this work indicate that the etching trajectories of nanocrystals are sensitive to the chemical nature of the redox additive and the etching behavior can be predicted by the electrochemical properties of the redox additive, which is consistent with the redox additive potential control hypothesis (Table S4).

The control of electrochemical reactions with redox additives is fundamentally different than typical the control obtained with three-electrode experiments. In bulk electrochemical experiments a potentiostat is used to control the potential at the surface of an electrode and measure current, and this can be used to precisely study electron transfer. However, electrochemical experiments do not directly provide structural information at the atomic scale. The control of electrochemical reactions with redox couples prevents the current associated with electron transfer from being measured directly but facilitates the observation of structural changes at near-atomic resolution with an electron microscope. Both techniques provide fundamentally different information that can be combined to further advance our understanding of electrochemical phenomena. The ability to control electrochemical reactions relies on an accurate understanding of the interactions between redox couples and radiolysis products, which could be influenced by factors such as liquid cell geometry, solution composition, and electron beam dose. It is important to conduct control 
experiments to understand the properties of a redox additive prior to studies of more complex electrochemical reactions. 


\section{Supporting figures}

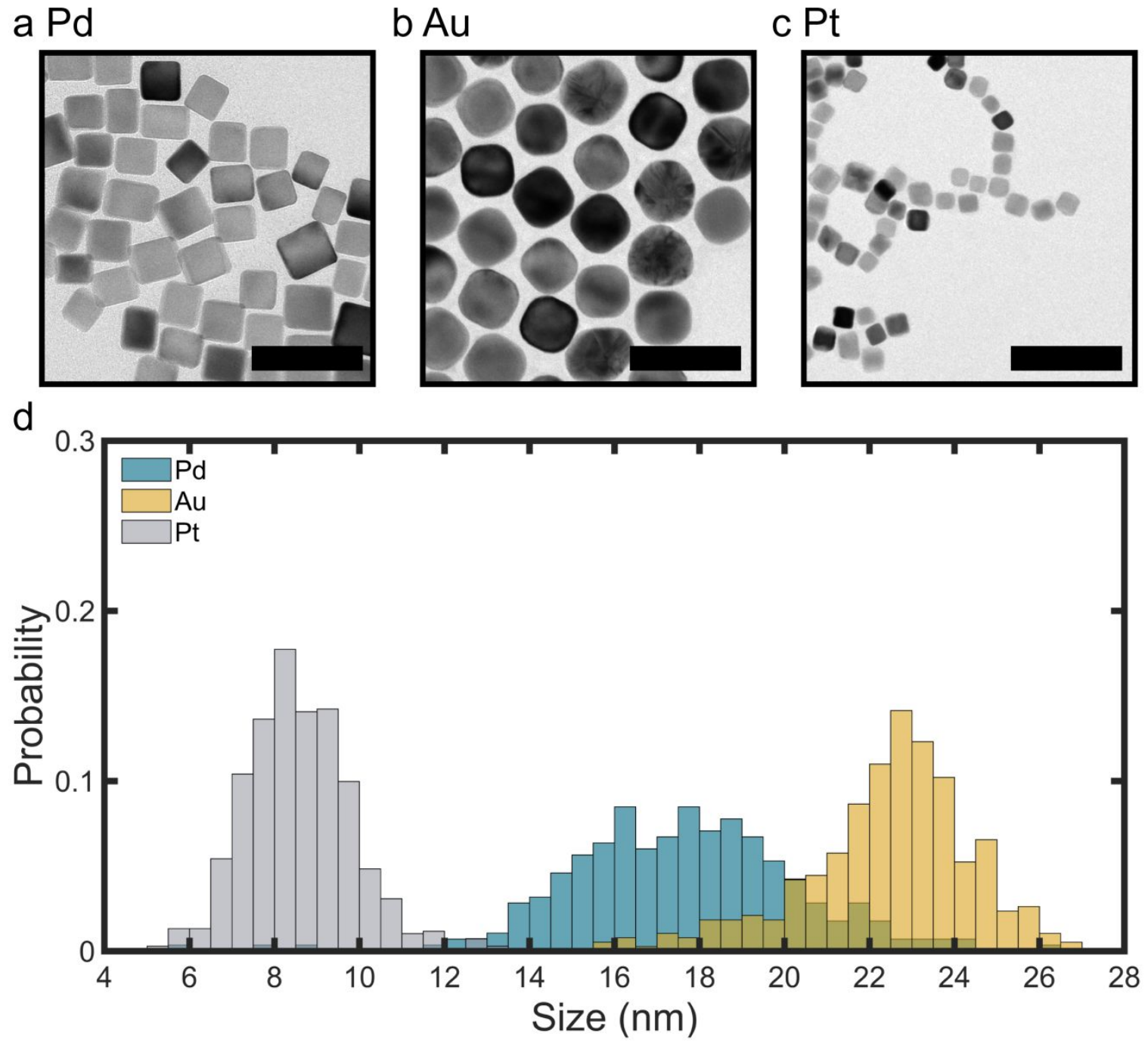

Figure S1. a-c) TEM images with $50 \mathrm{~nm}$ scale bars of Pd, Au, and Pt nanocrystals. d) Histogram of $\mathrm{Pd}, \mathrm{Au}$, and $\mathrm{Pt}$ nanocrystal sizes. 

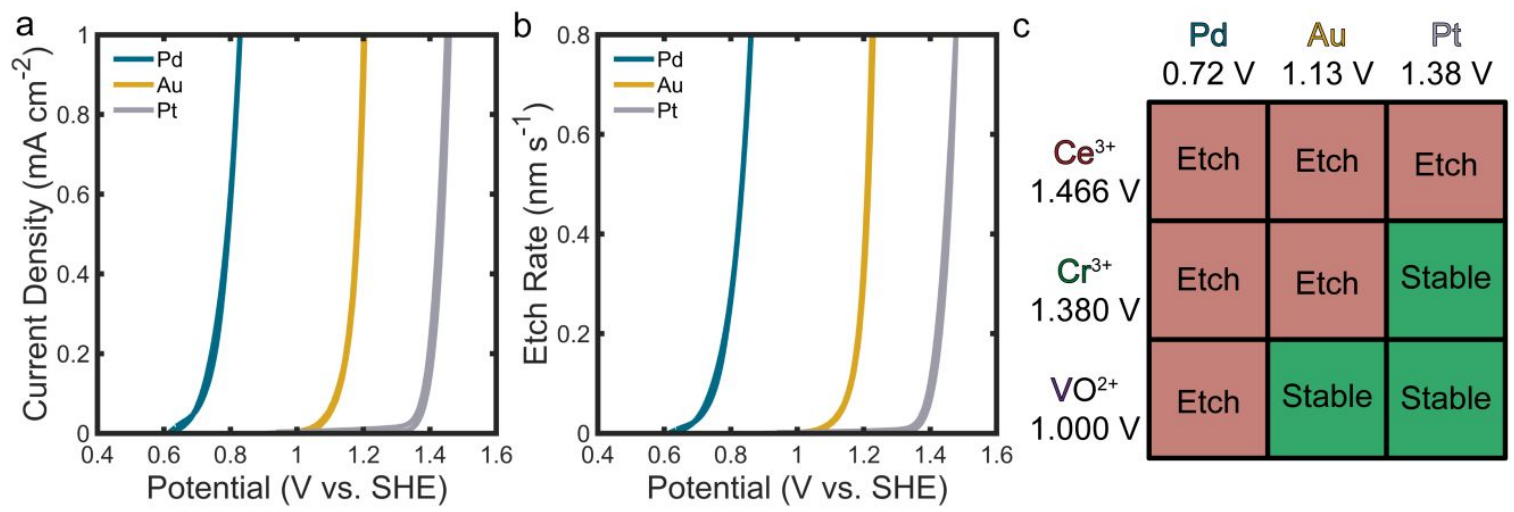

Figure S2. a) Cyclic voltammetry of $\mathrm{Pd}, \mathrm{Au}$, and Pt electrodes in $100 \mathrm{mM} \mathrm{HCl}$. b) Etch rates of metal electrodes determined assuming $100 \%$ Faradaic efficiency towards metal dissolution. c) Etching behavior predicted from the etch rates observed with cyclic voltammetry and the standard potentials of $\mathrm{V}(\mathrm{IV}) / \mathrm{V}(\mathrm{V}), \mathrm{Cr}(\mathrm{III}) / \mathrm{Cr}(\mathrm{VI})$, and $\mathrm{Ce}(\mathrm{III}) / \mathrm{Ce}(\mathrm{IV})$ redox couples.
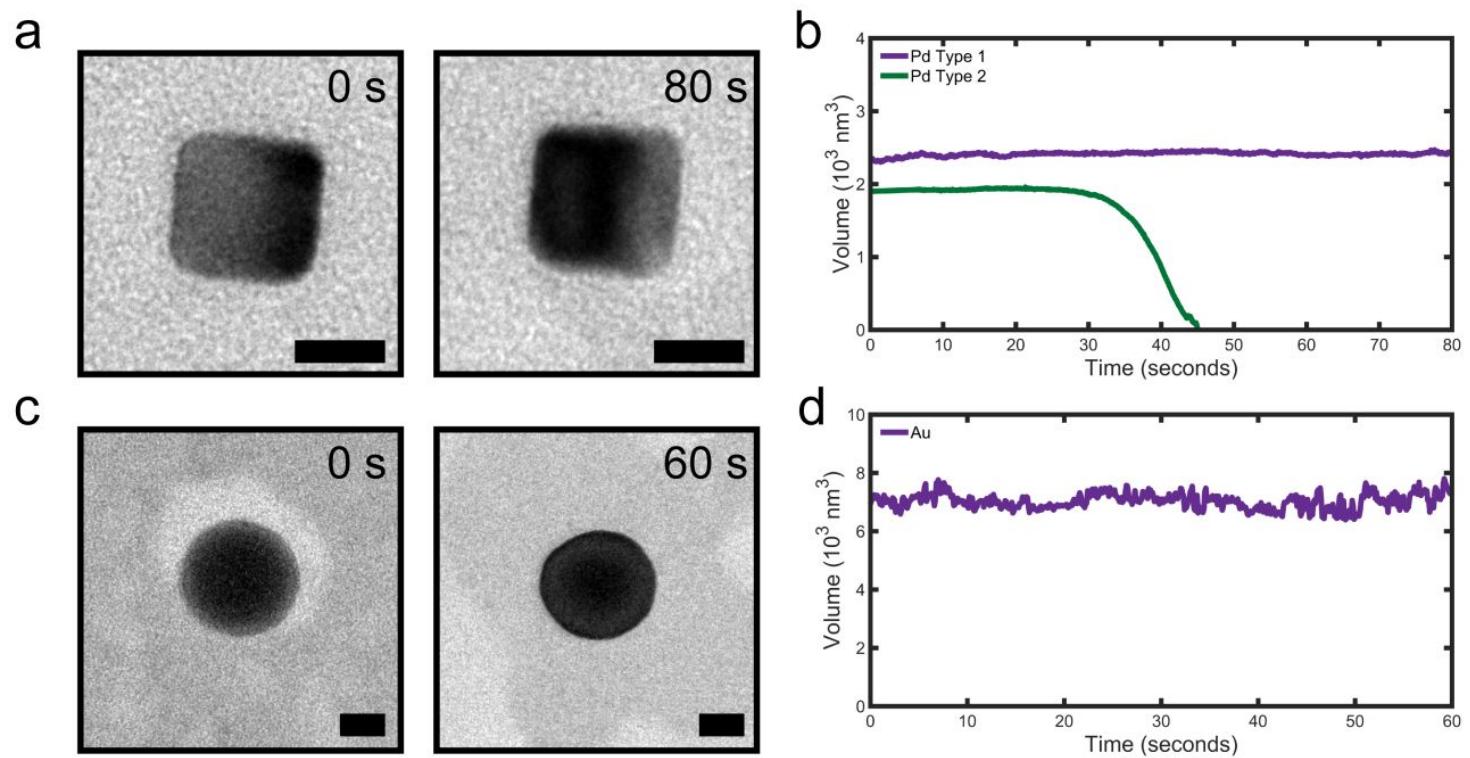

e
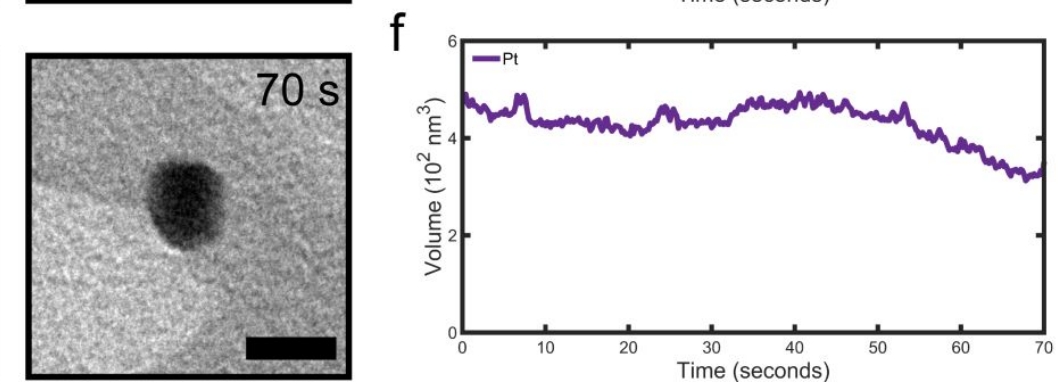

Figure S3. Representative Etching trajectories of $\mathrm{Pd}, \mathrm{Au}$, and $\mathrm{Pt}$ nanocrystals in solutions containing $10 \mathrm{mM} \mathrm{MgCl}$ and $100 \mathrm{mM} \mathrm{HCl}$. a-b) TEM images and volume trajectory of $\mathrm{Pd}$ nanocrystals. Two types of etching trajectories were observed. c-d) TEM images and volume trajectory of Au nanocrystals. e-f) TEM images and volume trajectory of Pt nanocrystals. Scale bars are $10 \mathrm{~nm}$. 

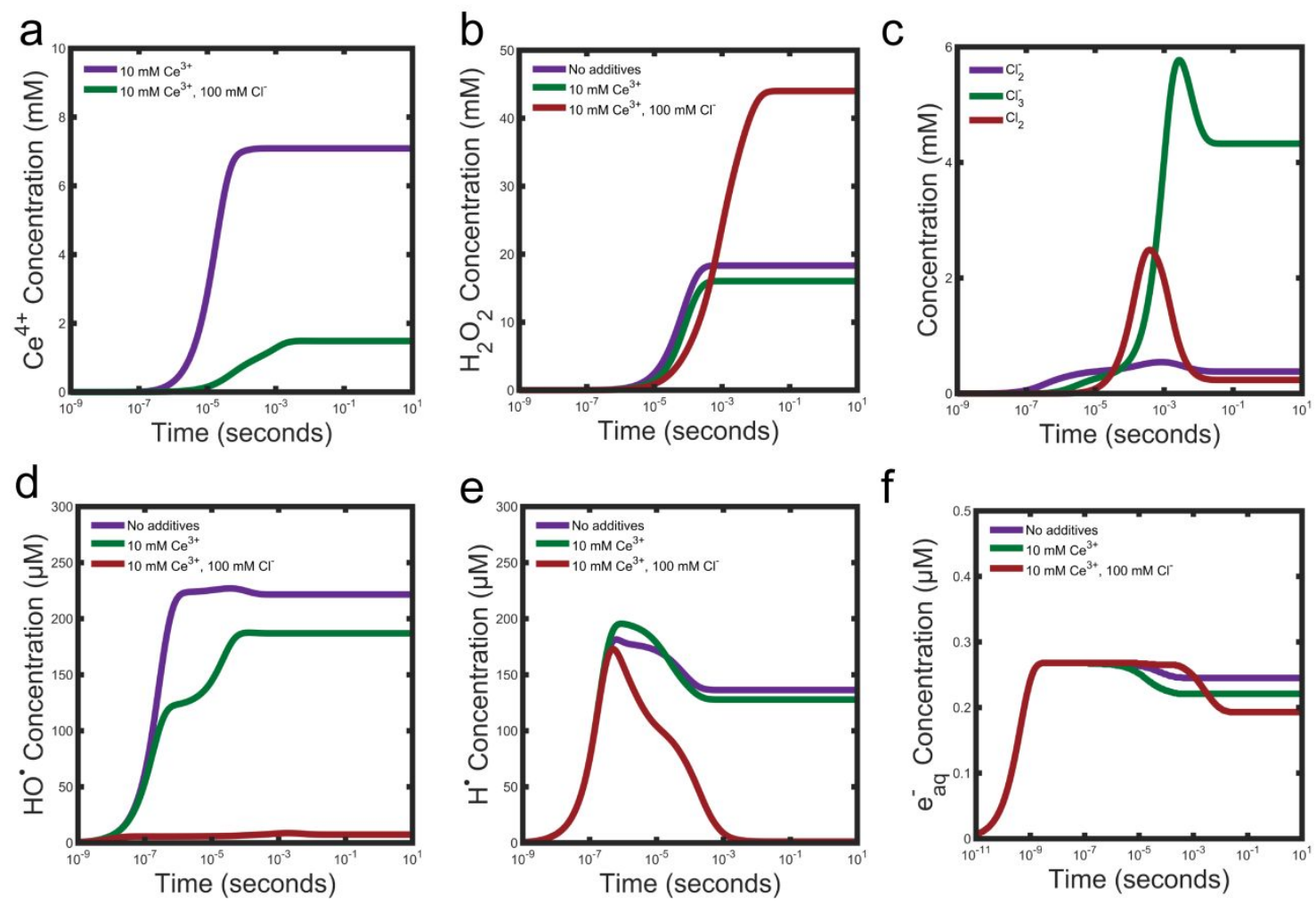

Figure S4. Results from the radiolysis chemical network model for an initial $\mathrm{pH}$ of 1 and an electron dose of $1200 \mathrm{e}^{-} \AA^{-2} \mathrm{~s}^{-1}$. a) Concentration profile of Ce(IV) for $10 \mathrm{mM} \mathrm{Ce(III)} \mathrm{with} \mathrm{and}$ without $100 \mathrm{mM} \mathrm{Cl}^{-}$. b) Concentration profile of hydrogen peroxide without additives, with 10 $\mathrm{mM} \mathrm{Ce}(\mathrm{III})$, and with $10 \mathrm{mM} \mathrm{Ce}(\mathrm{III})$ and $100 \mathrm{mM} \mathrm{Cl}^{-}$. c) Concentration profile of oxidized chlorine species with $10 \mathrm{mM} \mathrm{Ce}(\mathrm{III})$ and $100 \mathrm{mM} \mathrm{Cl}^{-}$. d-f) Concentration profile of hydroxyl radicals, atomic hydrogen, and solvated electrons without additives, with $10 \mathrm{mM} \mathrm{Ce}(\mathrm{III})$, and with $10 \mathrm{mM} \mathrm{Ce}(\mathrm{III})$ and $100 \mathrm{mM} \mathrm{Cl}^{-}$. 

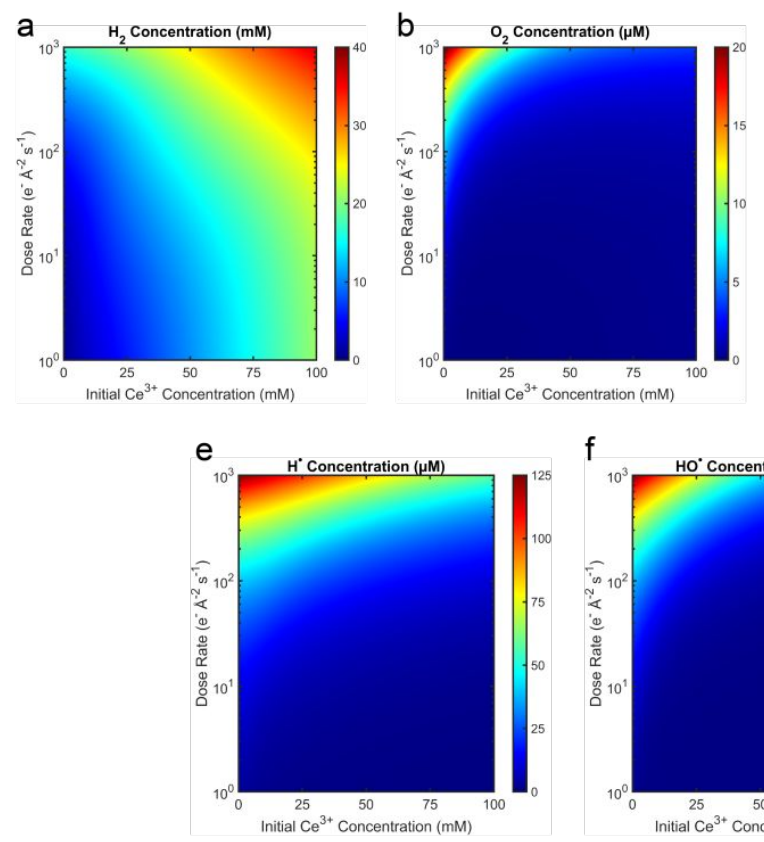
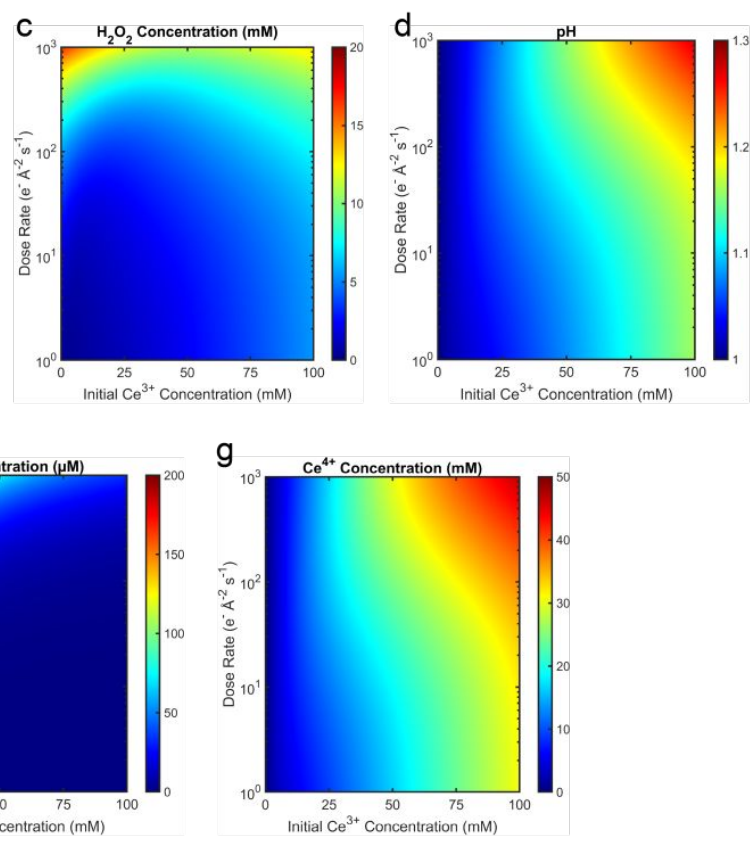

Figure S5. Steady-state concentrations of species obtained from the radiolysis chemical network model for different electron beam doses and initial $\mathrm{Ce}(\mathrm{III})$ concentrations. Initial species concentrations were $100 \mathrm{mM} \mathrm{H}^{+}$and $0-100 \mathrm{mM} \mathrm{Ce(III).} \mathrm{Steady-state} \mathrm{values} \mathrm{were} \mathrm{obtained} \mathrm{by}$ simulating the chemical environment for 1,000 seconds. a) Hydrogen. b) Oxygen. c) Hydrogen peroxide. d) $\mathrm{pH}$. e) Atomic hydrogen. f) Hydroxyl radical. g) $\mathrm{Ce}(\mathrm{IV})$. 

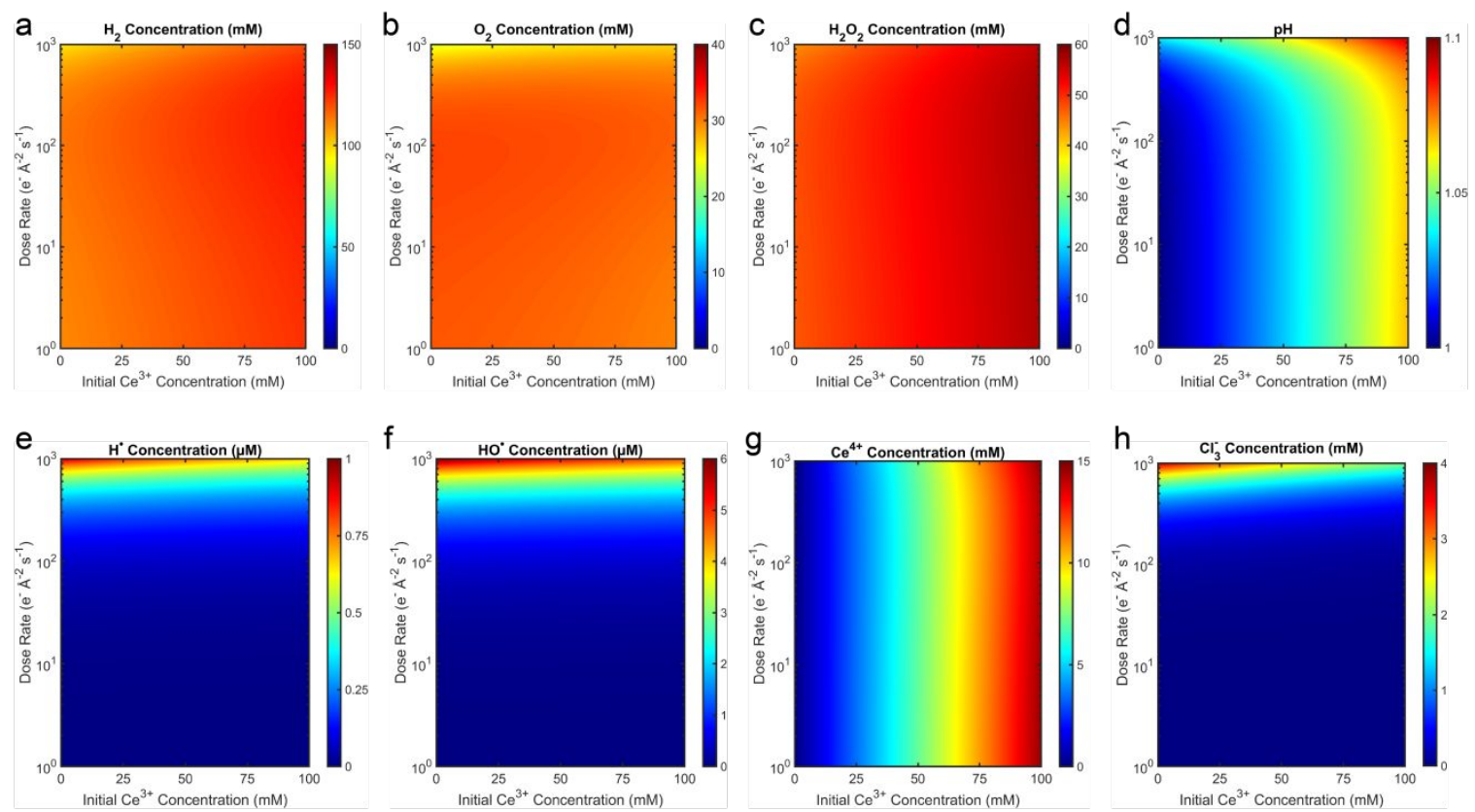

Figure S6. Steady-state concentrations of species obtained from the radiolysis chemical network model for different electron beam doses and initial $\mathrm{Ce}(\mathrm{III})$ concentrations. Initial species concentrations were $100 \mathrm{mM} \mathrm{H}^{+}, 100 \mathrm{mM} \mathrm{Cl}^{-}$, and $0-100 \mathrm{mM} \mathrm{Ce(III).} \mathrm{Steady-state} \mathrm{values} \mathrm{were}$ obtained by simulating the chemical environment for 1,000 seconds. a) Hydrogen. b) Oxygen. c) Hydrogen peroxide. d) $\mathrm{pH}$. e) Atomic hydrogen. f) Hydroxyl radicals. g) $\mathrm{Ce}(\mathrm{IV})$. h) $\mathrm{Cl}_{3}{ }^{-}$. 

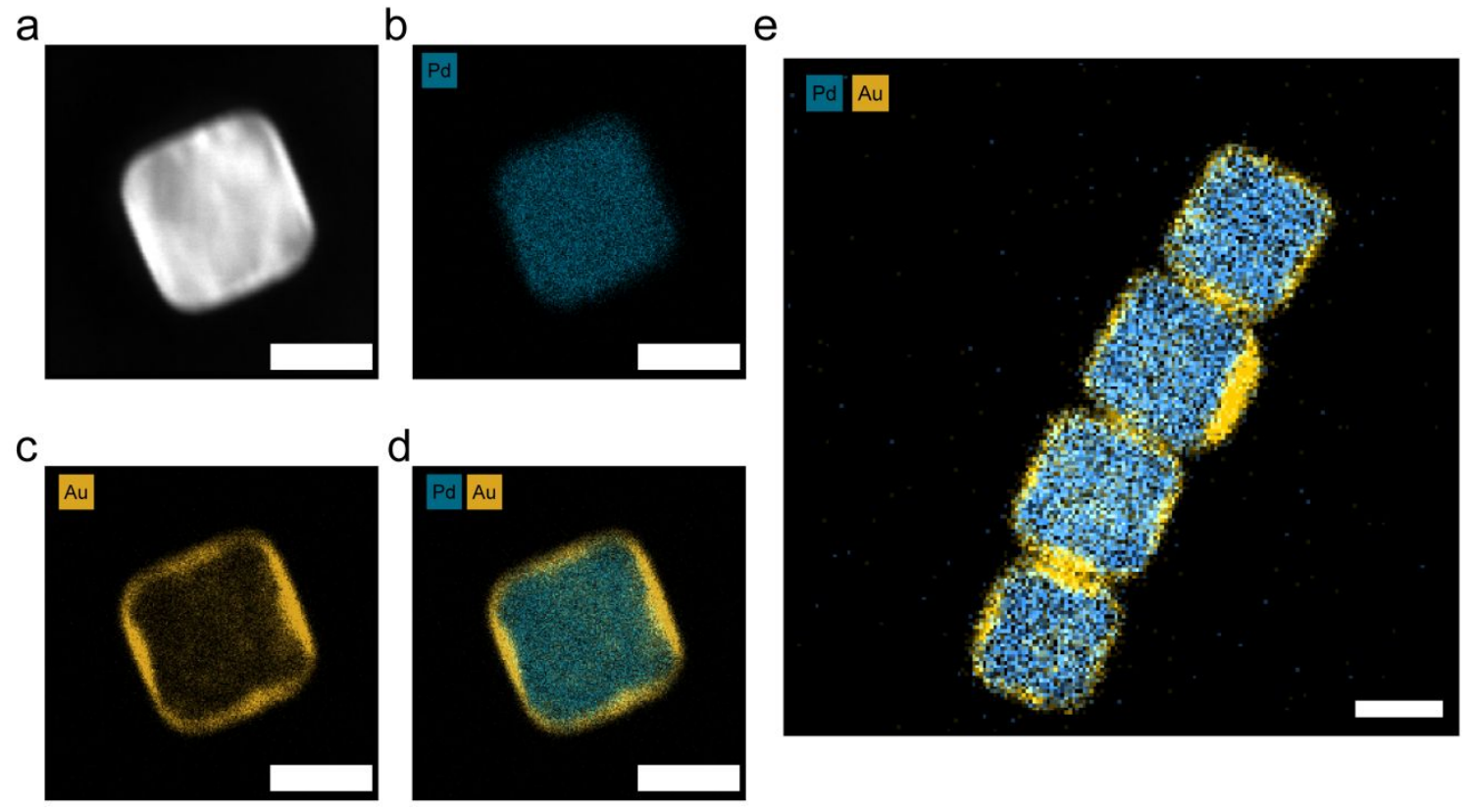

Figure S7. Elemental mapping of Pd@Au core-shell nanocrystals. a) High angle annular dark field STEM image of Pd@Au nanocrystal prepared with $50 \mu \mathrm{L} 1.0 \mathrm{mM} \mathrm{HAuCl}_{4}$. b-d) Corresponding elemental maps of Pd and Au collected from the K series for Pd and the L series for Au. e) Lowmagnification map of Pd@Au nanocrystal cluster. Scale bars are $20 \mathrm{~nm}$ in length. 

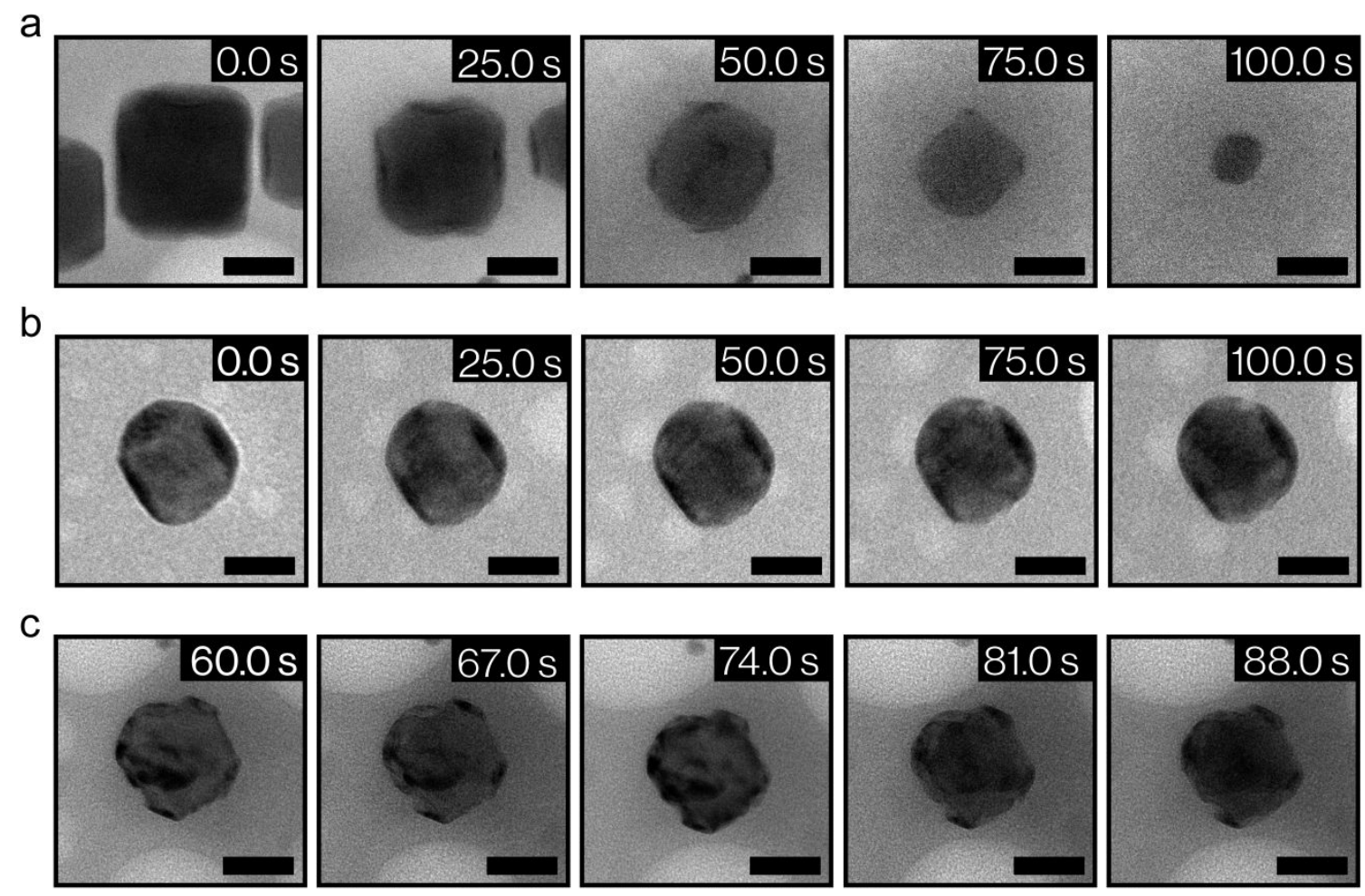

Figure S8. TEM image time series with $20 \mathrm{~nm}$ scale bars collected during irradiation of graphene liquid cells containing $10 \mathrm{mM} \mathrm{V(IV),100} \mathrm{mM} \mathrm{HCl,} \mathrm{and} \mathrm{Pd@Au} \mathrm{core-shell} \mathrm{nanocrystals.} \mathrm{a)}$ Nanocrystals prepared with $25 \mu \mathrm{L} \mathrm{HAuCl}_{4}$ and have a thinner gold shell. b) Nanocrystals prepared with $100 \mu \mathrm{L} \mathrm{HAuCl}_{4}$ and have a thicker gold shell. c) Final frames for nanocrystals prepared with $50 \mu \mathrm{L} \mathrm{HAuCl}_{4}$. 
a
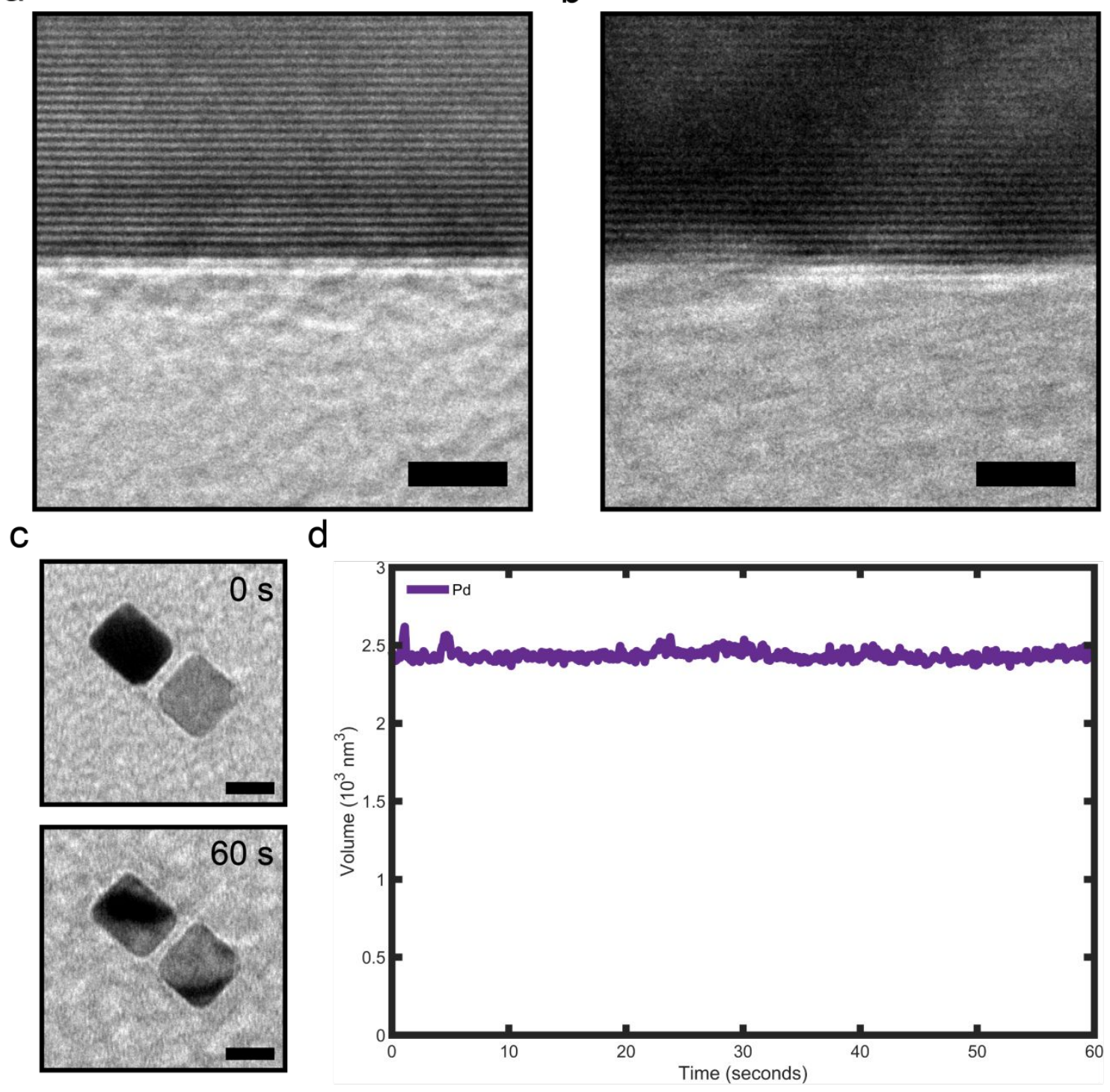

Figure S9. TEM images of Pd nanocrystals with $2 \mathrm{~nm}$ scale bars collected with an electron dose of $1200 \mathrm{e}^{-} \AA^{-2} \mathrm{~s}^{-1}$ and an exposure of 1 second. a) Image collected for a nanocrystal on a dry TEM grid. b) Image collected for a nanocrystal inside of a graphene liquid cell prepared with $10 \mathrm{mM}$ $\mathrm{Eu}(\mathrm{III})$ acetate and $100 \mathrm{mM} \mathrm{HCl}$. c-d) TEM image series and etching trajectory of a Pd nanocrystal in a graphene liquid cell prepared with $10 \mathrm{mM} \mathrm{Eu(III)}$ acetate and $100 \mathrm{mM} \mathrm{HCl}$. 
Table S1. Summary of the electrochemical half-reactions relevant to this work.

\begin{tabular}{ccc}
\hline Electrochemical Half-Reaction & $\begin{array}{c}\text { Potential } \\
(\text { V vs. SHE })\end{array}$ & Reference \\
\hline $\mathrm{H}_{2} \mathrm{O}+\mathrm{e}^{-} \rightarrow \mathrm{e}_{\mathrm{aq}}^{-}$ & -2.88 & 13 \\
$\mathrm{H}^{+}+\mathrm{e}^{-} \rightarrow \mathrm{H}^{-}$ & -2.31 & 13 \\
$\mathrm{Eu}^{3+}+\mathrm{e}^{-} \rightarrow \mathrm{Eu}^{2+}$ & -0.35 & 14 \\
$\mathrm{PdCl}_{4}^{2-}+2 \mathrm{e}^{-} \rightarrow \mathrm{Pd}^{2+} 4 \mathrm{Cl}^{-}$ & 0.59 & 14 \\
$\mathrm{PdO}+2 \mathrm{H}^{+}+2 \mathrm{e}^{-} \rightarrow \mathrm{Pd}^{-} \mathrm{H}_{2} \mathrm{O}$ & 0.79 & 14 \\
$\mathrm{PtCl}_{4}^{2-}+2 \mathrm{e}^{-} \rightarrow \mathrm{Pt}^{2}+4 \mathrm{Cl}^{-}$ & 0.758 & 14 \\
$\mathrm{VO}_{2}^{+}+2 \mathrm{H}^{+}+\mathrm{e}^{-} \rightarrow \mathrm{VO}^{2+}+\mathrm{H}_{2} \mathrm{O}$ & 1.000 & 14 \\
$\mathrm{AuCl}_{4}^{-}+3 \mathrm{e}^{-} \rightarrow \mathrm{Au}^{3} 4 \mathrm{Cl}^{-}$ & 1.002 & 14 \\
$\mathrm{HCrO}_{4}^{-}+7 \mathrm{H}^{+}+3 \mathrm{e}^{-} \rightarrow \mathrm{Cr}^{3+}+4 \mathrm{H}_{2} \mathrm{O}$ & 1.38 & 14 \\
$\mathrm{Cl}_{3}^{-}+2 \mathrm{e}^{-} \rightarrow 3 \mathrm{Cl}^{-}$ & 1.415 & 14 \\
$\mathrm{Ce}^{4+}+\mathrm{e}^{-} \rightarrow \mathrm{Ce}^{3+}$ & 1.466 & 15 \\
$\mathrm{Cl}_{2}{ }^{-}+\mathrm{e}^{-} \rightarrow 2 \mathrm{Cl}^{-}$ & 2.126 & 13 \\
$\mathrm{HO} \cdot+\mathrm{e}^{-}+\mathrm{H}^{+} \rightarrow \mathrm{H}_{2} \mathrm{O}$ & 2.730 & 13 \\
\hline
\end{tabular}

Table S2. Summary of redox reactions between $\mathrm{V}(\mathrm{IV}) / \mathrm{V}(\mathrm{V}), \mathrm{Cr}(\mathrm{III}) / \mathrm{Cr}(\mathrm{VI})$, or $\mathrm{Ce}(\mathrm{III}) / \mathrm{Ce}(\mathrm{IV})$ redox species and radicals generated from water radiolysis.

\begin{tabular}{|c|c|c|c|c|}
\hline $\begin{array}{c}\text { Redox } \\
\text { Species }\end{array}$ & $\begin{array}{c}\text { Radiolysis } \\
\text { Species }\end{array}$ & Balanced Chemical Reaction & Reaction Rate & Reference \\
\hline $\mathrm{Ce}^{3+}$ & $\mathrm{OH}^{\cdot}$ & $\mathrm{Ce}^{3+}+\mathrm{OH}^{\cdot} \rightarrow \mathrm{Ce}^{4+}+\mathrm{OH}^{-}$ & $3.0 \times 10^{8}$ & 16 \\
\hline $\mathrm{Ce}^{4+}$ & $\mathrm{e}_{\mathrm{aq}}^{-}$ & $\mathrm{Ce}^{4+}+\mathrm{e}_{\mathrm{aq}}^{-} \rightarrow \mathrm{Ce}^{3+}$ & $6.6 \times 10^{10}$ & 17 \\
\hline $\mathrm{Ce}^{4+}$ & $\mathrm{H}^{\circ}$ & $\mathrm{Ce}^{4+}+\mathrm{H}^{\cdot} \stackrel{-4}{\rightarrow} \mathrm{Ce}^{3+}+\mathrm{H}^{+}$ & $6.6 \times 10^{7}$ & 17 \\
\hline $\mathrm{VO}^{2+}$ & $\mathrm{OH}^{\cdot}$ & $\mathrm{VO}^{2+}+\mathrm{OH}^{\cdot} \rightarrow \mathrm{VO}_{2}^{+}+\mathrm{H}^{+}$ & $2.5 \times 10^{8}$ & 18 \\
\hline $\mathrm{VO}_{2}^{+}$ & $\mathrm{H}^{\cdot}$ & $\mathrm{VO}_{2}^{+}+\mathrm{H}^{\cdot}+\mathrm{H}^{+} \rightarrow \mathrm{VO}^{2+}+\mathrm{H}_{2} \mathrm{O}$ & $8.0 \times 10^{9}$ & 17 \\
\hline $\mathrm{Cr}^{3+}$ & $\mathrm{OH}^{\cdot}$ & $\mathrm{Cr}^{3+}+3 \mathrm{OH}^{\cdot}+\mathrm{H}_{2} \mathrm{O} \rightarrow \mathrm{HCrO}_{4}^{--}+4 \mathrm{H}^{+}$ & Multiple steps & 19 \\
\hline $\mathrm{HCrO}_{4}^{-}$ & $\mathrm{H}^{\cdot}$ & $\mathrm{HCrO}_{4}^{-}+3 \mathrm{H}^{-}+4 \mathrm{H}^{+} \rightarrow \mathrm{Cr}^{3+}+4 \mathrm{H}_{2} \mathrm{O}$ & Multiple steps & 20 \\
\hline $\mathrm{Eu}^{3+}$ & $\mathrm{e}_{\mathrm{aq}}{ }^{-}$ & $\mathrm{Eu}^{3+}+\mathrm{e}_{\mathrm{aq}}^{-} \rightarrow \mathrm{Eu}^{2+}$ & $6.1 \times 10^{10}$ & 16 \\
\hline $\mathrm{Eu}^{2+}$ & $\mathrm{OH}^{\circ}$ & $\mathrm{Eu}^{2+}+\mathrm{OH}^{-} \rightarrow \mathrm{Eu}^{3+}+\mathrm{OH}^{-}$ & $9.0 \times 10^{8}$ & 21 \\
\hline
\end{tabular}


Table S3. Summary of chemical reactions observed with liquid cell electron microscopy. The standard Gibbs free energy is reported per mole of metal dissolved.

\begin{tabular}{|c|c|c|c|}
\hline Metal & Oxidant & Balanced Chemical Reaction & $\begin{array}{c}\Delta \mathrm{G} \\
\left(\mathrm{kJ} \mathrm{mol}^{-1}\right)\end{array}$ \\
\hline $\mathrm{Pd}$ & $\mathrm{VO}_{2}^{+}$ & $\mathrm{Pd}+4 \mathrm{Cl}^{-}+2 \mathrm{VO}_{2}^{+}+4 \mathrm{H}^{+} \rightarrow \mathrm{PdCl}_{4}^{2-}+2 \mathrm{VO}^{2+}+2 \mathrm{H}_{2} \mathrm{O}$ & -73.3 \\
\hline $\mathrm{Pd}$ & $\mathrm{HCrO}_{4}^{-}$ & $3 \mathrm{Pd}+12 \mathrm{Cl}^{-}+2 \mathrm{HCrO}_{4}^{-}+14 \mathrm{H}^{+} \rightarrow 3 \mathrm{PdCl}_{4}^{2-}+2 \mathrm{Cr}^{3+}+8 \mathrm{H}_{2} \mathrm{O}$ & -146.7 \\
\hline $\mathrm{Pd}$ & $\mathrm{Ce}^{4+}$ & $\mathrm{Pd}+4 \mathrm{Cl}^{-}+2 \mathrm{Ce}^{4+} \rightarrow \mathrm{PdCl}_{4}^{2-}+2 \mathrm{Ce}^{3+}$ & -163.3 \\
\hline $\mathrm{Au}$ & $\mathrm{VO}_{2}^{+}$ & $\mathrm{Au}+4 \mathrm{Cl}^{-}+3 \mathrm{VO}_{2}^{+}+6 \mathrm{H}^{+} \rightarrow \mathrm{AuCl}_{4}^{-}+3 \mathrm{VO}^{2+}+6 \mathrm{H}_{2} \mathrm{O}$ & 0.6 \\
\hline $\mathrm{Au}$ & $\mathrm{HCrO}_{4}^{-}$ & $\mathrm{Au}+4 \mathrm{Cl}^{-}+\mathrm{HCrO}_{4}^{-}+7 \mathrm{H}^{+} \rightarrow \mathrm{AuCl}_{4}^{-}+\mathrm{Cr}^{3+}+4 \mathrm{H}_{2} \mathrm{O}$ & -109.4 \\
\hline $\mathrm{Au}$ & $\mathrm{Ce}^{4+}$ & $\mathrm{Au}+4 \mathrm{Cl}^{-}+3 \mathrm{Ce}^{4+} \rightarrow \mathrm{AtCl}_{4}^{-}+3 \mathrm{Ce}^{3+}$ & -136.6 \\
\hline $\mathrm{Pt}$ & $\mathrm{VO}_{2}^{+}$ & $\mathrm{Pt}+4 \mathrm{Cl}^{-}+2 \mathrm{VO}_{2}^{+}+4 \mathrm{H}^{+} \rightarrow \mathrm{PtCl}_{4}^{2-}+2 \mathrm{VO}^{2+}+2 \mathrm{H}_{2} \mathrm{O}$ & -46.7 \\
\hline $\mathrm{Pt}$ & $\mathrm{HCrO}_{4}^{-}$ & $3 \mathrm{Pt}+12 \mathrm{Cl}^{-}+2 \mathrm{HCrO}_{4}^{-}+14 \mathrm{H}^{+} \rightarrow 3 \mathrm{PtCl}_{4}^{2-}+2 \mathrm{Cr}^{3+}+8 \mathrm{H}_{2} \mathrm{O}$ & -120.0 \\
\hline $\mathrm{Pt}$ & $\mathrm{Ce}^{4+}$ & $\mathrm{Pt}+4 \mathrm{Cl}^{-}+2 \mathrm{Ce}^{4+} \rightarrow \mathrm{PtCl}_{4}^{2-}+2 \mathrm{Ce}^{3+}$ & -134.3 \\
\hline
\end{tabular}

Table S4. Summary of etch rates observed during liquid cell electron microscopy experiments and electrochemical predictions. The kinetic potential was calculated using the etching onset potential observed for metal electrodes and the standard potential for the redox couples.

\begin{tabular}{ccccc}
\hline Metal & Oxidant & $\begin{array}{c}\text { Kinetic Potential } \\
(\mathrm{V})\end{array}$ & $\begin{array}{c}\text { Electrochemical } \\
\text { Prediction }\end{array}$ & $\begin{array}{c}\text { Median Etch Rate } \\
\left(\mathrm{nm} \mathrm{s}^{-1}\right)\end{array}$ \\
\hline $\mathrm{Pd}$ & $\mathrm{VO}_{2}{ }^{+}$ & 0.280 & Etch & 0.08 \\
$\mathrm{Pd}$ & $\mathrm{HCrO}_{4}^{-}$ & 0.660 & Etch & 0.50 \\
$\mathrm{Pd}$ & $\mathrm{Ce}^{4+}$ & 0.756 & Etch & 0.59 \\
$\mathrm{Au}$ & $\mathrm{VO}_{2}{ }^{+}$ & -0.130 & Stable & 0.01 \\
$\mathrm{Au}$ & $\mathrm{HCrO}_{4}$ & 0.250 & Etch & 0.31 \\
$\mathrm{Au}$ & $\mathrm{Ce}^{4+}$ & 0.336 & Etch & 1.39 \\
$\mathrm{Pt}$ & $\mathrm{VO}_{2}{ }^{+}$ & -0.380 & Stable & 0.00 \\
$\mathrm{Pt}$ & $\mathrm{HCrO}_{4}^{-}$ & 0.000 & Stable & 0.00 \\
$\mathrm{Pt}$ & $\mathrm{Ce}^{4+}$ & 0.086 & Etch & 0.19 \\
\hline
\end{tabular}


Table S5. Summary of Chemical Reactions Included in Homogeneous Chemical Network Model.

\begin{tabular}{|c|c|c|c|}
\hline $\begin{array}{l}\text { Reaction } \\
\text { Number }\end{array}$ & Reaction & $\begin{array}{c}\text { Reaction } \\
\text { Constant } \\
\left(\mathrm{M}^{-1} \mathrm{~s}^{-1} \text { or } \mathrm{s}^{-1}\right)\end{array}$ & Reference \\
\hline 74 & $\mathrm{OH}^{\bullet}+\mathrm{Cl}^{-} \rightarrow \mathrm{ClOH}^{-}$ & $4.3 \times 10^{9}$ & 8 \\
\hline 75 & $\mathrm{ClOH}^{\cdot-} \rightarrow \mathrm{OH}^{\bullet}+\mathrm{Cl}^{-}$ & $6.1 \times 10^{9}$ & 8 \\
\hline 76 & $\mathrm{Cl}^{\cdot}+\mathrm{Cl}^{-} \rightarrow \mathrm{Cl}_{2}^{\cdot-}$ & $8.5 \times 10^{9}$ & 8 \\
\hline 77 & $\mathrm{H}^{+}+\mathrm{ClOH}^{\cdot-} \rightarrow \mathrm{Cl}^{\cdot}+\mathrm{H}_{2} \mathrm{O}$ & $2.1 \times 10^{10}$ & 8 \\
\hline 78 & $\mathrm{ClOH}^{\cdot-} \rightarrow \mathrm{Cl}^{\bullet}+\mathrm{OH}^{-}$ & $2.3 \times 10^{1}$ & 8 \\
\hline 79 & $\mathrm{Cl}^{\cdot}+\mathrm{OH}^{-} \rightarrow \mathrm{ClOH}^{\cdot-}$ & $1.8 \times 10^{10}$ & 8 \\
\hline 80 & $\mathrm{Cl}_{2}^{\cdot-} \rightarrow \mathrm{Cl}^{\bullet}+\mathrm{Cl}^{-}$ & $6.0 \times 10^{4}$ & 8 \\
\hline 81 & $\mathrm{Cl}_{2}^{\bullet^{-}}+\mathrm{Cl}_{2}^{\bullet^{-}} \rightarrow \mathrm{Cl}_{3}^{-}+\mathrm{Cl}^{-}$ & $2.0 \times 10^{9}$ & 8 \\
\hline 82 & $\mathrm{Cl}^{\cdot}+\mathrm{Cl}_{2}^{\cdot-} \rightarrow \mathrm{Cl}_{3}^{-}$ & $6.3 \times 10^{8}$ & 8 \\
\hline 83 & $\mathrm{Cl}^{-}+\mathrm{Cl}_{2} \rightarrow \mathrm{Cl}_{3}^{-}$ & $1.0 \times 10^{4}$ & 8 \\
\hline 84 & $\mathrm{Cl}_{3}^{-} \rightarrow \mathrm{Cl}^{-}+\mathrm{Cl}_{2}$ & $5.0 \times 10^{4}$ & 8 \\
\hline 85 & $\mathrm{Cl}^{\cdot}+\mathrm{Cl}^{\cdot} \rightarrow \mathrm{Cl}_{2}$ & $8.8 \times 10^{7}$ & 8 \\
\hline 86 & $\mathrm{e}_{\mathrm{aq}}^{-}+\mathrm{Cl}^{\cdot} \rightarrow \mathrm{Cl}^{-}$ & $1.0 \times 10^{10}$ & 8 \\
\hline 87 & $\mathrm{e}_{\mathrm{aq}}^{-}+\mathrm{Cl}_{2}^{\cdot-} \rightarrow 2 \mathrm{Cl}^{-}$ & $1.0 \times 10^{10}$ & 8 \\
\hline 88 & $\mathrm{e}_{\mathrm{aq}}^{-}+\mathrm{Cl}_{3}^{-} \rightarrow \mathrm{Cl}^{-}+\mathrm{Cl}_{2}^{\cdot-}$ & $3.0 \times 10^{10}$ & 8 \\
\hline 89 & $\mathrm{H}^{\bullet}+\mathrm{Cl}^{\bullet} \rightarrow \mathrm{H}^{+}+\mathrm{Cl}^{-}$ & $1.0 \times 10^{10}$ & 8 \\
\hline 90 & $\mathrm{H}^{\bullet}+\mathrm{Cl}_{2}^{\cdot-} \rightarrow \mathrm{H}^{+}+2 \mathrm{Cl}^{-}$ & $8.0 \times 10^{9}$ & 8 \\
\hline 91 & $\mathrm{H}^{\bullet}+\mathrm{Cl}_{3}^{-} \rightarrow \mathrm{H}^{+}+\mathrm{Cl}^{-}+\mathrm{Cl}_{2}^{\cdot-}$ & $1.0 \times 10^{10}$ & 8 \\
\hline 92 & $\mathrm{HO}_{2}{ }^{-}+\mathrm{Cl}_{2}^{\cdot-} \rightarrow 2 \mathrm{Cl}^{-}+\mathrm{O}_{2}+\mathrm{H}^{+}$ & $1.0 \times 10^{9}$ & 8 \\
\hline 93 & $\mathrm{HO}_{2}^{\cdot}+\mathrm{Cl}_{2} \rightarrow \mathrm{Cl}_{2}^{\cdot-}+\mathrm{O}_{2}+\mathrm{H}^{+}$ & $1.0 \times 10^{9}$ & 22 \\
\hline 94 & $\mathrm{Ce}^{4+}+\mathrm{e}_{\mathrm{aq}}^{-} \rightarrow \mathrm{Ce}^{3+}$ & $6.6 \times 10^{10}$ & 17 \\
\hline 95 & $\mathrm{Ce}^{4+}+\mathrm{H}^{\cdot} \stackrel{\mathrm{Ce}^{3+}}{\rightarrow}+\mathrm{H}^{+}$ & $6.6 \times 10^{7}$ & 17 \\
\hline 96 & $\mathrm{Ce}^{3+}+\mathrm{OH}^{\cdot} \rightarrow \mathrm{Ce}^{4+}+\mathrm{OH}^{-}$ & $3.0 \times 10^{8}$ & 16 \\
\hline
\end{tabular}


Supporting Movie 1. In-situ TEM movie montage of Pd, $\mathrm{Au}$, or Pt nanocrystals in graphene liquid cells prepared with $10 \mathrm{mM} \mathrm{V(IV)} \mathrm{and} 100 \mathrm{mM} \mathrm{HCl}$ at an electron dose of $1200 \mathrm{e}^{-} \AA^{-2} \mathrm{~s}^{-1}$.

Supporting Movie 2. In-situ TEM movie montage of $\mathrm{Pd}, \mathrm{Au}$, or Pt nanocrystals in graphene liquid cells prepared with $10 \mathrm{mM} \mathrm{Cr}(\mathrm{III})$ and $100 \mathrm{mM} \mathrm{HCl}$ at an electron dose of $1200 \mathrm{e}^{-} \AA^{-2} \mathrm{~s}^{-1}$.

Supporting Movie 3. In-situ TEM movie montage of Pd, $\mathrm{Au}$, or Pt nanocrystals in graphene liquid cells prepared with $10 \mathrm{mM} \mathrm{Ce}(\mathrm{III})$ and $100 \mathrm{mM} \mathrm{HCl}$ at an electron dose of $1200 \mathrm{e}^{-} \AA^{-2} \mathrm{~s}^{-1}$.

Supporting Movie 4. In-situ TEM movie of Pd and Au nanocrystals in a graphene liquid cell prepared with $10 \mathrm{mM} \mathrm{V(IV)} \mathrm{and} 100 \mathrm{mM} \mathrm{HCl}$ at an electron dose of $1200 \mathrm{e}^{-} \AA^{-2} \mathrm{~s}^{-1}$.

Supporting Movie 5. In-situ TEM movie of Au and Pt nanocrystals in a graphene liquid cell prepared with $10 \mathrm{mM} \mathrm{Cr}(\mathrm{III})$ and $100 \mathrm{mM} \mathrm{HCl}$ at an electron dose of $1200 \mathrm{e}^{-} \AA^{-2} \mathrm{~s}^{-1}$.

Supporting Movie 6. In-situ TEM movie montage of Pd@Au nanocrystals synthesized with 25, 50 , or $100 \mu \mathrm{L}$ of $1 \mathrm{mM} \mathrm{HAuCl}$ in graphene liquid cells prepared with $10 \mathrm{mM} \mathrm{V(IV)} \mathrm{and} 100 \mathrm{mM}$ $\mathrm{HCl}$ at an electron dose of $1200 \mathrm{e}^{-} \AA^{-2} \mathrm{~s}^{-1}$.

Supporting Movie 7. In-situ TEM movie montage of Pd, $\mathrm{Au}$, or Pt nanocrystals in graphene liquid cells prepared with $10 \mathrm{mM} \mathrm{MgCl}_{2}$ and $100 \mathrm{mM} \mathrm{HCl}$ at an electron dose of $1200 \mathrm{e}^{-} \AA^{-2} \mathrm{~s}^{-1}$. 


\section{References}

(1) Niu, W.; Li, Z.-Y.; Shi, L.; Liu, X.; Li, H.; Han, S.; Chen, J.; Xu, G., Seed-Mediated Growth of Nearly Monodisperse Palladium Nanocubes with Controllable Sizes. Crys. Growth Des. 2008, 8 (12), 4440-4444.

(2) Lim, B.; Kobayashi, H.; Yu, T.; Wang, J.; Kim, M. J.; Li, Z.-Y.; Rycenga, M.; Xia, Y., Synthesis of Pd-Au Bimetallic Nanocrystals via Controlled Overgrowth. J. Am. Chem. Soc. 2010, 132, 2506-2507.

(3) Wu, H. L.; Kuo, C. H.; Huang, M. H., Seed-mediated synthesis of gold nanocrystals with systematic shape evolution from cubic to trisoctahedral and rhombic dodecahedral structures. Langmuir 2010, 26 (14), 12307-13.

(4) Yu, T.; Kim, D. Y.; Zhang, H.; Xia, Y., Platinum concave nanocubes with high-index facets and their enhanced activity for oxygen reduction reaction. Angew. Chem. Int. Ed. 2011, 50 (12), 2773-7.

(5) Alivisatos Github Repository. https://github.com/AliviGitHub.

(6) Schneider, N. M.; Norton, M. M.; Mendel, B. J.; Grogan, J. M.; Ross, F. M.; Bau, H. H., Electron-Water Interactions and Implications for Liquid Cell Electron Microscopy. J. Phys. Chem. C 2014, 118, 22373-22382.

(7) Elliot, A. J.; McCracken, D. R., Computer modelling of the radiolysis in an aqueous lithium salt blanket: Suppression of radiolysis by addition of hydrogen. Fusion Eng. Des. 1990, 13 (1), 21-27.

(8) El Omar, A. K.; Schmidhammer, U.; Rousseau, B.; LaVerne, J.; Mostafavi, M., Competition Reactions of $\mathrm{H}_{2} \mathrm{O}^{\cdot+}$ Radical in Concentrated $\mathrm{Cl}^{-}$Aqueous Solutions: Picosecond Pulse Radiolysis Study. J. Phys. Chem. A 2012, 116 (47), 11509-18.

(9) Cherevko, S.; Zeradjanin, A. R.; Topalov, A. A.; Kulyk, N.; Katsounaros, I.; Mayrhofer, K. J. J., Dissolution of Noble Metals during Oxygen Evolution in Acidic Media. ChemCatChem 2014, $6(8), 2219-2223$.

(10) Pizzutilo, E.; Geiger, S.; Freakley, S. J.; Mingers, A.; Cherevko, S.; Hutchings, G. J.; Mayrhofer, K. J. J., Palladium electrodissolution from model surfaces and nanoparticles. Electrochim. Acta 2017, 229, 467-477.

(11) de Jonge, N.; Houben, L.; Dunin-Borkowski, R. E.; Ross, F. M., Resolution and aberration correction in liquid cell transmission electron microscopy. Nat. Rev. Mater. 2018, 4 (1), 61-78. (12) Yuk, J. M.; Park, J.; Ercius, P.; Kim, K.; Hellebusch, D. J.; Crommie, M. F.; Lee, J. Y.; Zettl, A.; Alivisatos, A. P., High-Resolution EM of Colloidal Nanocrystal Growth Using Graphene Liquid Cells. Science 2012, 336 (6077), 61-64.

(13) Armstrong, D. A.; Huie, R. E.; Koppenol, W. H.; Lymar, S. V.; Merényi, G.; Neta, P.; Ruscic, B.; Stanbury, D. M.; Steenken, S.; Wardman, P., Standard electrode potentials involving radicals in aqueous solution: inorganic radicals (IUPAC Technical Report). Pure Appl. Chem. 2015, 87 (11-12), 1139-1150.

(14) Bard, A. J.; Parsons, R.; Jordan, J., Standard Potentials in Aqueous Solution. Marcel Dekker: 1985.

(15) Maverick, A. W.; Yao, Q., The Cerium(IV)/Cerium(III) Electrode Potential in Hydrochloric Acid Solutio. Inorg. Chem. 1993, 32, 5626-5628.

(16) Buxton, G. V.; Greenstock, C. L.; Helman, W. P.; Ross, A. B., Critical Review of Rate Constants for Reactions of Hydrated Electrons, Hydrogen Atoms and Hydroxyl Radicals $\left(\cdot \mathrm{OH} / \mathrm{O}^{-}\right)$in Aqueous Solution. J. Phys. Chem. Ref. Data 1988, 17 (2), 513-886. 
(17) Gogolev, A. V.; Shilov, V. P.; Fedoseev, A. M.; Pikaev, A. K., The study of reactivity of actinide ions towards hydrated electrons and hydrogen atoms in acid aqueous solutions by a pulse radiolysis method. Int. J. Radiat. Appl. Instrum., Part C 1991, 37 (3), 531-535.

(18) Samuni, A.; Meisel, D.; Czapski, G., The kinetics of the oxidation of chromium(II), titanium(III), and vanadium(IV) by hydrogen peroxide and hydroxyl radicals. J. Chem. Soc, Dalton Trans. 1972, 1273-1277.

(19) Buxton, G. V.; Djouider, F.; Lynch, D. A.; Malone, T. N., Oxidation of $\mathrm{Cr}^{\mathrm{III}}$ to $\mathrm{Cr}^{\mathrm{VI}}$ initiated by ${ }^{\circ} \mathrm{OH}$ and $\mathrm{SO}_{4}{ }^{-}$in acidic aqueous solution A pulse radiolysis study. J. Chem. Soc. Faraday Trans. 1997, 93 (24), 4265-4268.

(20) Sharpe, P. H. G.; Sehested, K., The dichromate dosimeter: A pulse-radiolysis study. Int. J. Radiat. Appl. Instrum., Part C 1989, 34 (5), 763-768.

(21) Faraggi, M.; Tendler, Y., Pulse Radiolysis in Lanthanide Aqueous Solutions. I. Formation Spectrum and Chemical Properties of Divalent Europium, Ytterbium, and Samarium Ions. $J$. Chem. Phys. 1972, 56, 3287-3293.

(22) Bjergbakke, E.; Navaratnam, S.; Parsons, B. J.; Swallow, A. J., Reaction between $\mathrm{HO}_{2}{ }^{\bullet}$ and Chlorine in Aqueous Solution. J. Am. Chem. Soc. 1981, 103, 5629-5928. 